\title{
LA RETRACTACIÓN EN LA ACEPTACIÓN DE RESPONSABILIDAD UNILATERAL. EL CASO COLOMBIANO A PARTIR DE LA JURISPRUDENCIA*
}

Gabriel Andrés Moreno Castañeda

\section{Resumen}

La jurisprudencia de la Sala de Casación Penal de la Corte Suprema de Justicia desde los albores de la Ley 906 de 2004, ha develado problemas serios en torno a la retractación en la aceptación de responsabilidad unilateral -conocida también como allanamiento puro y simple-. Este artículo, que se construye desde la historiografía de la jurisprudencia vigente y la doctrina especializada, presenta una revisión de los vacíos normativos y jurisprudenciales sobre el tema y concluye sobre la posibilidad del retracto. Se busca determinar si es posible, a la luz del contexto normativo colombiano, la viabilidad de aceptar la retractación en el interregno que va de la audiencia de formulación de la imputación a la audiencia de acusación. La tesis dominante de la jurisprudencia ordinaria penal niega esa posibilidad; creemos que dicha posición es errada, conforme se verá más adelante.

\section{Palabras claves}

Allanamiento a cargos, acuerdos, manifestaciones preacordadas de culpabilidad, justicia premial, retractación, jurisprudencia.

\begin{abstract}
The jurisprudence of the Criminal Cassation Chamber of the Supreme Court of Justice since the dawn of Law 906 of 2004, has revealed serious problems regarding the retraction in the acceptance of unilateral responsibility - also known as pure and simple acceptance acquiescence. This article, which is built from the historiography of current jurisprudence and specialized doctrine, presents a review of the normative and jurispruden-
\end{abstract}

\footnotetext{
* Trabajo para optar al título de Maestro en Derecho Procesal Penal; dirigido por el Maestro Rodrigo Javier Parada Rueda LLM.

** Abogado de la Universidad Autónoma de Bucaramanga; Especialista en Derecho Penal de la Universidad Autónoma de Bucaramanga; Maestro en Derecho de la Universidad Sergio Arboleda. E-mail: Gabrigabrielmoreno_@hotmail.com; gabrielandresmorenocastaneda@ gmail.com
} 
tial gaps on the subject and concludes on the possibility of retraction. It seeks to determine if it is possible, in light of the Colombian regulatory context, the feasibility of accepting the retraction in the interregnum that goes from the hearing to formulate the imputation to the accusatory hearing. The dominant thesis of ordinary criminal jurisprudence denies that possibility; We believe that this position is wrong, as will be seen later.

\section{Keywords}

Acquiescence to charges, agreements, pre-agreed statements of guilt, premial justice, retraction, jurisprudence.

\section{Introducción}

La mayoría de los institutos que pertenecen al proceso penal con tendencia acusatoria (L. 906/2004), entre ellos la aceptación de responsabilidad -o también llamado allanamiento a cargos- y la retractación, han sido desarrollados por la jurisprudencia de la Sala de Casación Penal de la Corte Suprema de Justicia en menor o en mayor medida. Dichas figuras, consagradas legalmente en nuestro contexto, provienen de procedimientos foráneos inclinados al derecho penal premial (Reyes, 2010; Guerrero, 2011; Manco, 2012; Castaño, 2013; Posada, 2015; Sentencia de febrero 21 de 2013, Tribunal Superior de Pereira). El presente trabajo, parte del análisis del avance -o por qué no, retroceso- de la jurisprudencia penal en torno a la retractación de la aceptación de cargos y tiene como objetivo establecer si resulta válido que el imputado que los ha aceptado en la audiencia preliminar de imputación, pueda retractarse antes de que el juez de conocimiento emita la sentencia. Este cuestionamiento, surge a partir de dos hechos concretos: el primero tiene que ver con los reiterados errores que se advierten en la praxis judicial al respecto y, el segundo, obedece a la confusión doctrinaria que no ha sido aclarada por la jurisprudencia de la Sala de Casación Penal de la Corte Suprema de Justicia.

Esta investigación resulta pertinente, tanto en el ámbito foráneo como en el interno, en principio, porque el desarrollo doctrinal en el derecho comparado, respecto a la posibilidad que tiene el imputado para retractarse de la aceptación de culpabilidad es escaso, así que este primer acercamiento pretende despertar interés para que la exploración académica dedique mayores líneas al desafío planteado. Es claro, conforme la experiencia lo muestra, que no son pocos los eventos en los que dicha posibilidad se presenta, razón por la que se hace necesaria una exploración académica profunda al respecto. En segundo lugar, porque en el ámbito interno, si bien por vía jurisprudencial la postura ha variado de acuerdo con el tratamiento legal de la figura del retracto, lo cierto es que la solución que se plantea por ese medio privilegia principios como la eficacia en el ejercicio de la administración de justicia y la lealtad procesal, por encima de garantías como la de no auto incriminación, la controversia de la prueba y la posibilidad de acceder a un juicio oral, público, concentrado y con todas las garantías.

Respecto a la metodología empleada, la investigación que se aborda es de tipo jurídico, pues se quiere determinar cuál ha sido es el tratamiento que la Sala de Casación Penal de la Corte Suprema de Justicia le ha dado a la retractación en la acep- 
tación de culpabilidad pura y simple; conforme a ello, la exploración académica realizada se orienta a partir del Código de Procedimiento Penal (L. 906/2004) y de la jurisprudencia nacional que se ocupa del retracto. El enfoque es histórico-hermenéutico y se consultan fuentes secundarias, a saber: doctrina especializada y jurisprudencia de la Corte Constitucional.

\section{La justicia premial en el nuevo proceso penal (L. 906/2004)}

Son múltiples los cambios que el Acto Legislativo 03 de 2002 introdujo al proceso penal, entre los cuales pueden señalarse: la separación clara e inequívoca de las funciones de acusación y juzgamiento que permite despojar al juez de la potestad que tenía en la ley 600 de 2000 de promover la acción penal en la fase de juzgamiento (Bernal, 2005) o en palabras de Verger "la jurisdicción [ya no tiene] control sobre la formulación o no de la acusación" (1994, p. 42), la adversariedad como expresión del principio acusatorio cuyos orígenes para un sector de la doctrina se encuentran en la Grecia antigua y no en el sistema continental europeo (Díaz, 2014, p. 43), la publicidad e inmediatez de la prueba, la reserva judicial para afectar derechos fundamentales y, el que más interesa para los objetivos de este trabajo, la incorporación del Derecho Penal Premial (Castaño, 2013) al cual pertenecen tanto la justicia premial como la justicia consensual o consensuada.

Valga la redundancia, el derecho premial hace referencia "al uso de premios y castigos con diversos fines" (Manco, 2012, p. 191) o es también la renuncia del Estado "a la acción penal, a la pena o a parte de ella, como contraprestación a la colaboración que el delincuente le puede ofrecer" (González, 2012, p. 4). Se trata, pues, de instrumentos que en últimas buscan mejorar la eficiencia del Estado, quien, a su vez, tendrá que ceder una porción de su pretensión punitiva como gesto compensatorio con el imputado o acusado que ha decido renunciar al juicio oral y ha optado por la vía abreviada solucionar la cuestión criminal.

Ahora bien, aunque este trabajo no tiene por objeto discutir acerca de la justicia premial, tampoco puede dejar de señalar las importantes consecuencias que una tal clase de justicia trae consigo. Entre las más notorias y principales, se encuentra la renuncia "forzada" a la garantía de tener un juicio oral, público, contradictorio y con inmediación de la prueba, a cambio de la promesa que el Estado le hace al imputado o acusado de concederle un premio que, en la mayoría de las veces, consiste en reducirle la pena de prisión y / o reconocerle beneficios judiciales (suspensión condicional de la ejecución de la pena, prisión domiciliaria, entre otras). Esto, en últimas, representa una relativización del proceso justo que desarrolla el artículo 29 de la Constitución Política, pues una parte importante de las garantías que integran su núcleo esencial (Sentencia T-039 de 1996, CConst.), como el derecho de contradicción, la carga de la prueba en cabeza del Estado, el derecho de defensa, la presunción de inocencia, entre otros, se rescinden para darle paso a una política criminal basada en el pragmatismo (García de Paz, 2005; Castaño, 2013).

Lo dicho anteriormente se nota más en los preacuerdos y negociaciones que en los mal llamados allanamientos (Molina, 2015), puesto que, en aquellos, la renun- 
cia no es totalmente libre, sino que está precedida de la pomposa promesa premial que hace el Estado al imputado o acusado para que desista de tales garantías judiciales y contribuya a:
"ahorrarse el juicio". Contrario sensu, en la hipótesis de la aceptación de responsabili- dad simple -denominados de forma equivocada allanamiento a cargos-, la persona que está siendo procesada escoge libremente y sin presión alguna aceptar los cargos imputados. Esta decisión -materialmente aunque no de manera formal- puede de- pender de circunstancias tales como: i) haber sido capturado en flagrancia o no; ii) la contundencia de los elementos materiales probatorios; iii) la conciencia de haber participado en el delito. Adicionalmente, hay que recordar que, así como la persona imputada no puede ser obligada a auto incriminarse, el derecho también debe repu- tarse constitucional cuando decide sin apremio alguno levantar ese fuero y declarar- se culpable de los cargos. Lo importante es que lo haga libremente y no interferido por promesas de reconocimiento de beneficios o amenazado por sanciones drásticas por parte de la Fiscalía General de la Nación que, a no dudarlo, tiene una posición dominante (Manco, 2012, p. 191).

Una segunda consecuencia no menos importante que la anterior en torno al tipo de justicia que se comenta, es la atinente a la verdad. En la doctrina existe consenso en cuanto a que la verdad se obtiene a través del proceso penal y la sentencia es donde esa verdad se recoge (Ostos, 2015); sin embargo, aunque ella pueda carecer de exactitud, en el trámite ordinario existen mayores probabilidades de acercarse a lo realmente acontecido, de ahí el "mote" de verdad real en contraposición a la verdad formal (Ostos, 2015) que destaca a trámites abreviados, preacuerdos y negociaciones como "la manifestación voluntaria y unilateral de aceptación de cargos" (Sarabia, 2013, p. 2). Una mayor profundidad en la crítica que aquí se hace, llevaría a indicar sin ambages que la búsqueda de la verdad se favorece en mayor medida en los procesos de tendencia inquisitiva continental que en los procesos acusatorios de corte anglosajón, pues en aquellos existe "una aplicación fuerte de la legalidad y la obligatoriedad que tiene la fiscalía para perseguir todos los delitos sin acudir a ningún tipo de negocio con el presunto criminal" (Manco, 2012, p. 192). Por lo contrario, en el sistema adversarial, aunque se afirme que la verdad se construye (Bernal \& Montealegre, 2013), lo cierto es que dadas las características que lo definen, el juez no deja de ser más que un garante del principio de igualdad de armas o un "árbitro que no busca el esclarecimiento de los hechos y la verdad material, sino el equilibrio" (Manco, 2012, p. 192), lo que en últimas, beneficia el aparecimiento de instrumentos de justicia premial como la aceptación unilateral de cargos y las negociaciones y preacuerdos, los cuales terminan arrojando una verdad que puede tildarse de "simbólica" (Molina, 2015, p. 140), como resultado del proceso penal.

De otra parte, en el proceso penal actual (L. 906/2004), los "allanamientos" puros y simples, los preacuerdos o negociaciones y el principio de oportunidad forman parte del tipo de justicia que se viene comentando. Estos mecanismos de justicia premial no son nuevos en el proceso penal colombiano, tampoco lo son en el mundo. En cuanto a esto último, se sabe que, solo hasta el siglo XVIII se alzaron 
voces contra la desproporcionalidad tanto de las penas como de los medios para adjudicar responsabilidad penal, lo cual fue suelo propicio para la aparición de los modernos sistemas penales en los que se busca estimular fallos condenatorios sin agotarse todas las etapas del procedimiento, sino basados en la confesión, la conformidad o el allanamiento del procesado a los cargos contra él formulados. Con posterioridad, se avanzó hacia la justicia negociada en la que, si bien persiste la obligación de investigar respecto del órgano de persecución penal, lo cierto es que se otorga alta preponderancia a la culminación anticipada del proceso -ya sea por aceptación de responsabilidad del acusado o por acuerdos a los que pueda arribar en aras de obtener beneficios punitivos-, la cual ha de mantenerse dentro del respeto a las garantías fundamentales y la aplicación del contenido principialístico de la ley penal. No por otra razón, en la actualidad se hace necesario que el operador judicial verifique la existencia de un mínimo de evidencia que inculpe al procesado a efectos de verificar si la aceptación de cargos-simple o negociada- se muestra acorde al deber probatorio del Estado y se desvirtúa la presunción de inocencia del sujeto pasivo de la acción penal.

Por su parte, en el ámbito local, la justicia premial se advierte en sus inicios en la ley $2^{\text {a }}$ de 1984. Esta norma reconocía, a quien aportara prueba de responsabilidad contra las personas que hubiesen hecho parte del delito, una rebaja de pena de una tercera parte a la mitad. Así mismo, en el Decreto 2700 de 1991, en el trámite de la audiencia especial, la fiscalía estaba autorizada para adelantar acuerdos en torno a la "adecuación típica, el grado de participación, la forma de culpabilidad, las circunstancias del delito, la pena y la condena de ejecución condicional, la preclusión por otros comportamientos sancionados con pena menor, siempre y cuando (hubiese) duda probatoria sobre su existencia" (C. P. P., art. 37A). Qué decir de los descuentos punitivos que ofrece la ley 600 de 2000 por confesión y sentencia anticipada (C. P. P., art. 40).

Esta historiografía, evidencia cómo los mecanismos de justicia premial han formado parte importante de la política criminal del Estado (Manco, 2012), sin embargo, aunque puedan ser consideradas herramientas válidas para mejorar la percepción colectiva de eficiencia de la administración de justicia (Sentencias de septiembre 7 de 2006, Radicado: 25765, CSJ; febrero 13 de 2008, Radicado: 28553 CSJ; septiembre 14 de 2009, Radicado: 32032, CSJ), no puede desconocerse que en la actualidad la justicia negociada ha empezado a ser vista como una privatización del proceso (Velásquez, 2010) o como la manifestación de una crisis del procedimiento penal producto de la influencia del plea bargaining norteamericano (Schünemann, 2002) o una súplica negociada (Gómez, 2008); en tal sentido, gran parte de la literatura alemana se opone a que un proceso penal fundado sobre el principio acusatorio "se convierta en un proceso de partes al estilo del proceso civil" (Bernal \& Montealegre, 2013, t. II, p. 862). Además, de la evidente discusión que se ha originado en torno a la crisis en la que son puestos varios derechos y garantías fundamentales (Guerrero, 2011; Montañez, 2014). 


\section{Mecanismos de justicia premial que actualmente hacen parte del proceso penal colombiano}

El actual modelo de enjuiciamiento criminal (L. 906/2004) dispone de tres recursos de justicia premial, a saber: los "allanamientos" simples o aceptación unilateral de culpabilidad, los preacuerdos y negociaciones, y el principio de oportunidad, los cuales buscan "la efectividad material de la administración de justicia dentro del marco propio de celeridad y economía" (Fierro, 2012, p. 224). Las diferencias entre una y otra figura son innegables. Dejando de un lado el último de los institutos pues no tiene semejanza alguna con lo que se plantea en este trabajo, se empezará por los preacuerdos, pues la primera de las figuras merece, conforme a los objetivos aquí trazados, un mayor desarrollo.

\section{Los preacuerdos o alegaciones de culpabilidad preacordadas.}

El instituto ha sido una verdadera revolución en el proceso penal, aunque, como ya se anotó, los negocios penales o "trueque entre la fiscalía y el acusado" (Muñoz, 2006, p. 231) no son cuestión de ahora, pues el Decreto 2700 de 1991 también contemplaba esta posibilidad. Evidentemente, la figura corresponde a una importación del derecho procesal penal anglosajón (Muñoz, 2006; Reyes, 2010; Guerrero, 2011; Manco, 2012; Castaño, 2013; Bernal \& Montealegre, 2013) y en ella se autoriza a las partes a transar la acción penal, es decir, negociar la responsabilidad y la consecuencia punitiva con el objetivo de, por un lado, simplificar la tarea de la fiscalía $y$, por el otro, que el imputado o acusado obtenga una rebaja sustancial de la pena o se le reconozca un beneficio judicial. Es decir, implica que el procesado renuncie a una de las etapas del proceso y, con ello, a la controversia de la prueba, a cambio de un beneficio de orden punitivo, el cual depende del momento procesal en que se produzca; a cambio de ello, la fiscalía -que representa al Estado- ahorra esfuerzos en la administración de justicia y materializa el principio de celeridad procesal (Sentencia de febrero 21 de 2007, Radicado 26587, CSJ).

Esta forma de terminación "anormal" o anticipada del proceso penal, a pesar de ser diametralmente opuesta a la tradición continental en tanto la fiscalía, por ejemplo, con el objetivo de lograr el acuerdo de culpabilidad y mostrar resultados de eficiencia, relativiza el principio de legalidad y desiste del deber constitucional que tiene de esclarecer los hechos que puedan constituir un delito y buscar la verdad material (Manco, 2012; Castaño, 2013), ha tenido una gran acogida por los operadores judiciales del país. La introducción de las negociaciones, además, hoy día representa "unos porcentajes muy superiores respecto de los procesos que, de verdad, se llevan a juicio" como se afirma desde la óptica del derecho comparado (De Diego, 1999, p. 39), de esta manera se afirma que en los eventos de aceptación de responsabilidad (negociada o unilateral) desaparecen las garantías que caracterizan las actuaciones penales de raigambre constitucional y con ello la causa penal termina convirtiéndose en "un proceso sin proceso" (Langbein, 1996, p. 46).

Ahora bien, al margen de las críticas que la doctrina especializada ha formulado al tema (Schünemann, 2002 y 2007; Velásquez, 2010; Guerrero, 2011; Castaño, 2013; 
Montañez, 2014), conviene precisar que a diferencia de los mal llamado "allanamientos", los preacuerdos o negociaciones, son un acto bilateral que se rige por el principio de autonomía de las partes, quienes deciden conforme a los linderos que traza la ley procesal penal, la Constitución Política y las Directivas expedidas por la Fiscalía General de la Nación, "disciplinar la relación por sí mismos" (Hinestrosa, 1986, p. 11). Esto se traduce en que ambas partes convienen y definen los términos del negocio penal, el cual finalmente deberá ser presentado al juez de conocimiento para que lo apruebe o impruebe. Adviértase que, precisamente, por el hecho de que son "las partes" las que pactan ninguno de los intervinientes procesales tiene posibilidad de vetar el acuerdo celebrado. Podrán exponer sus posiciones, por supuesto, pero no deben los pactantes atenerse a las inquietudes que se les planteen. Incluso, el juez no podrá hacer recomendaciones frente a lo pactado debiéndose ceñir a aprobar o improbar lo que ha sido objeto de negociación.

\section{La retractación en los preacuerdos y negociaciones.}

La idea expuesta en el acápite precedente, sugiere con claridad que los preacuerdos son una especie de negocio penal que surge a partir de la voluntad expresa o tácita de las partes de querer arreglar el asunto penal. La Sala de Casación Penal de la Corte Suprema de Justicia ha interpretado algunas veces que, así como la autonomía de la voluntad influye decisivamente en la confección del acuerdo, también el retracto aparece gobernado por aquél derecho o poder (Hinestrosa, 1986) reconocido a las partes para que una de ellas sin explicaciones pueda desconocer los términos del convenio. La cuestión, sin embargo, no ha sido pacífica.

\section{Observemos:}

[...] la retractación -en trámites de terminación abreviada- sólo tiene cabida respecto de los preacuerdos y únicamente antes de que el juez de conocimiento imparta su aprobación en la audiencia que para el efecto ha de citar, conforme el artículo 293 inciso 2. Tal forma de reversar una situación procesal plena y legalmente estructurada es refractaria a la forma de aceptación de cargos en la modalidad de allanamiento (Sentencia de octubre 22 de 2008, Radicado: 29983, CSJ).

Acorde con el anterior criterio, tal parece -de manera tácita- que la Corte Suprema de Justicia, Sala de Casación Penal, no sólo convalidó el retracto en los preacuerdos sino que también determinó que esa posibilidad no reside de forma exclusiva en una de las dos partes; es decir, tanto fiscalía como imputado o acusado pueden deshacer el negocio, salvo que el juez de conocimiento haya impartido aprobación al mismo, evento éste en el que habrá de concurrir una de las hipótesis de que trata parágrafo del artículo 293 de la Ley 906 de 2004 para que prospere el desasimiento. Se trata, pues, de actos de plena autonomía tanto en la celebración del negocio penal como en la escisión de éste y, quiérase o no, la autorización que el alto tribunal concede a las partes para reversar lo pactado, no es más que la incorporación al proceso penal del principio de la autonomía de la voluntad, base esencialísima sobre la cual se construyen los negocios jurídicos en el ámbito privado. Así claramente lo dijo la Sala de Casación Penal: 
[C]uando se acude a la definición natural del término y a la forma como es tratado en el artículo 293 de la Ley 906 de 2004, necesariamente se debe concluir, por esencia, que el retracto informa de la posibilidad o facultad, derivada de la simple voluntad, de desdecirse de una actuación o manifestación. En otros términos, si la ley consagra para el preacuerdo la posibilidad de retractarse, que opera, en términos del artículo 293 en cita, respecto de "alguno de los intervinientes", ello no alude a la existencia de vicios o defectos que tornen inane esa manifestación de voluntad común inserta en el escrito firmado, sino, como en el apotegma del derecho referido a que las cosas se deshacen como se hacen, a que esa misma voluntad permita a alguna de las partes echarse atrás, sin necesidad de explicar su querer o demostrar la existencia de circunstancias particulares que den al traste con el pacto (Sentencia de marzo 21 de 2012, Radicado 38500, CSJ).

De igual modo, en otra decisión el alto tribunal reiteró que, de la lectura del precepto legal en cita de precedencia, la única prohibición de retractarse establecida es la que se genere luego de verificada la aceptación de responsabilidad, lo cual le corresponde al juez de conocimiento; lo dicho hasta aquí implica, de forma tácita, que en el interregno anterior, a saber, entre la aceptación de cargos y el acto de legalidad posterior, ante el juez encargado del juicio es procedente retractarse (Sentencia de mayo 30 de 2012, Radicado: 37668, CSJ). Así, pues, en materia de preacuerdos la jurisprudencia penal ha decantado conclusiones en torno a leyes que gobiernan los negocios jurídicos y, en esa medida, prohíja la idea de que las transacciones negociadas y su escisión a través del retracto se deben a la autonomía de cada parte. Sin embargo, esta postura fue revaluada en el año 2013 por el alto tribunal, al juzgar que el criterio expuesto en el radicado N. 37668 de 2012, se prestaba para que las partes, en especial el procesado, burlaran la administración de justicia y, por ello, la prosperidad del retracto quedó condicionada a que se demostrara una de las hipótesis que prevé el respectivo parágrafo, a saber: que el acuerdo no obedeciera a un acto voluntario, libre y espontáneo -vicios en el consentimiento-; o que en desarrollo de la aceptación se vulneraran garantías fundamentales (Sentencia de febrero 13 2013, Radicado 39707, CSJ).

Así las cosas, la Corte abandona la concepción privativista en materia negociaciones y retractación y, en adelante, condiciona el retracto a la demostración de un vicio en el consentimiento o una violación de garantías fundamentales. Este viraje, empieza ya a demostrar la ambigüedad en el tratamiento del asunto, pues en tanto una de ésas dos condiciones se materialicen (vicio o violación de garantías fundamentales), tal y como sucede en el derecho privado, en el caso de los vicios (excepto el error de derecho), el acuerdo deja de tener validez jurídica porque sobreviene la nulidad absoluta (C. C., art. 1741). Como más adelante podrá apreciarse de cara a la justificación del retracto en los casos de aceptación de culpabilidad unilateral o "allanamientos", el alto Tribunal confunde la autonomía de la voluntad que reside en las partes el derecho para crear y deshacer el negocio jurídico, con los vicios que afectan esa voluntad y, por tanto, llevan a la nulidad de lo pactado. La ambigüedad es más palmaria con lo que se sigue, pues cuando se trata de preacuerdos el máximo Tribunal de la Justicia Ordinaria hizo énfasis en que la retractación del imputado o acusado sin exigencia alguna, es permitida previo a que el acta de preacuerdo 
sea sometida a control judicial (Sentencia de febrero 13 de 2013, Radicado: 40053, CSJ; Sentencia STP223 de 2015, Radicado: 77358, CSJ).

Nótese, pues, como la retractación en los preacuerdos ha fluctuado entre dos tesis: una, un poder incondicionado que tienen las partes para ejercerlo y escindir el negocio penal sin cortapisa alguna (filosofía propia de los negocios jurídicos) y; otra, un poder que solamente puede ejercitarse en tanto se demuestre un vicio en el consentimiento o una violación de garantías fundamentales, cuestión última que resulta ser completamente errática, pues como ya se dijo, los vicios (error, fuerza, dolo) que afectan el consentimiento a la luz de las reglas civiles generan la nulidad del acuerdo y por lo tanto no pueden asimilarse a una retractación. Se trata de figuras diametralmente opuestas.

\section{La aceptación unilateral de cargos o los mal llamados allanamientos.}

Una primera cuestión que merece toda la claridad, es la atinente a la naturaleza jurídica de esa figura. En efecto, aunque el legislador y la jurisprudencia mucho aluden a ella para significar la aceptación unilateral por parte del imputado o acusado de los cargos que la Fiscalía General de la Nación le formula, lo cierto es que, en el plano de la reflexión académica, el allanamiento se asocia a la denominada teoría de la disponibilidad (Guerrero, 2011) que le permite a las partes en el procedimiento civil disponer "sobre el objeto del proceso" (Silvosa, 2008, p. 32); es decir, se trata de una figura más cercana al procedimiento civil que a los procedimientos penales.

En España, por ejemplo, se ha discutido si la conformidad, un instituto que es definido como "un acto de disposición sobre el contenido de la pretensión penal" (Molina, 2012, pp. 233-234), debe equipararse al allanamiento en el procedimiento civil, a una institución de carácter transaccional o si puede asemejarse a la confesión. Aguilera De Paz (citado por Vigil, 2012), en sus centenarios comentarios concebía la conformidad en el proceso penal como una forma de allanamiento, en la que el acusado renuncia a ejercer su derecho a la defensa, aceptando la pretensión de la acusación; de igual opinión otros catedráticos hispanos, quienes entienden que el sujeto pasivo pone fin al procedimiento mediante la aceptación de cumplimiento de la pretensión (Gimeno, 1999, p. 597).

Ahora bien, cuando la figura del allanamiento se traslada al procedimiento penal, la discusión mayor se centra en la disponibilidad de la acción. En efecto, mientras que en el procedimiento civil existe un principio dispositivo (Silvosa, 2008) que permite a la parte demandada declarar su conformidad con la pretensión del demandante y consecuentemente el juez queda vinculado a los hechos (Cortés, 1993; Mesa, 2004) sin opción de poder valorarlos o discutirlos; en el procedimiento penal, no hay tal disponibilidad, por lo menos, no de manera libre e incondicionada dado el derecho material que está en juego. Adicionalmente, es necesario tener en cuenta que en el procedimiento civil el allanamiento involucra una conformidad con una pretensión (López, 2016, p. 595; Sentís, 1958, p. 266) que en la mayoría de los casos se reduce a un asunto económico; en el proceso penal, ésa conformi- 
dad implica la renuncia a sagrados derechos fundamentales, y por ello mismo, no podría considerarse "una disponibilidad plena, sino condicionada que implica diferencias de fondo con el proceso civil" (Guerrero, 2011, p. 500) que debe superar el filtro de constitucionalidad que hace el juez de garantías o de conocimiento según la etapa en la que la persona voluntariamente decida asumir la responsabilidad penal por los cargos imputados.

En el ámbito nacional, Bazzani (2006) también se ha cuestionado la proximidad de ambos institutos, no obstante, a pesar de las claridades que puedan aportarse desde la doctrina, la jurisprudencia y en general los jueces de la República utilizan de manera impropia el término allanamiento para hacer referencia a la aceptación unilateral, voluntaria e incondicionada a los cargos. Así que, para no recaer en imprecisiones, en este trabajo, y para efectos prácticos, se hará uso del término "allanamiento", entendiendo que dicho concepto no es el apropiado en materia penal.

El "allanamiento" puro y simple radica en cabeza del imputado o acusado; es la decisión de aceptar unilateralmente los cargos formulados y a cambio de ello el Estado le ofrece una rebaja en la sanción punitiva acorde con el momento procesal en que haga la aceptación y las condiciones en que fue capturado (L. 906 / 2004, arts. 301 y 351; Sentencia de julio 11 de 2011, Radicado: 38285, CSJ). Ahora, conforme se indicó en sentencia C-303 del 2013 por la Corte Constitucional, el descuento que a cambio de la aceptación de cargos recibe el procesado, es equiparable realmente a un beneficio y no a un derecho, razón por la cual normas como la Ley 1098 de 2006 y 1121 de 2006, constituyen impedimentos para que al procesado se le reconozca descuento punitivo alguno y opta por aceptar los cargos que la hubieren formulado.

En la praxis judicial, los "allanamientos" son más viables en la primera salida procesal, es decir, en aquella oportunidad en la cual la Fiscalía General de la Nación cumple el deber que tiene de comunicar a la persona que cuenta con elementos materiales probatorios que permiten inferir razonablemente que es autora o partícipe de un hecho punible (Espitia, 2006). Se afirma que son comunes en esta instancia, por el monto de la rebaja que recibe el procesado, pues siempre que no se trate de un caso de flagrancia, el artículo 351 de la Ley 906 de 2004 contempla un descuento de hasta la mitad de la pena a imponer. Es de precisar que, el momento procesal aludido, comprende la formalización de la investigación, más no quiere decir que sólo a partir de él se amparen las garantías fundamentales, pues "el punto inicial [es] aquel momento en el que una persona es sindicada, de cualquier forma, como partícipe en un hecho punible" (Maier, 2002, p. 195), esto significa que las garantías se activan desde la fase de indagación (Sentencia C-799 de 2005, CConst.; Mendieta, 2014).

En todo caso, es válido afirmar que en la audiencia de formulación de imputación, el imputado se encuentra ante una encrucijada: de un lado, si decide no aceptar cargos se verá amparado por un "sistema procesal de tendencia acusatoria propio de un régimen democrático" (Urbano, 2008, p. 16), es decir, amparado en el 
reconocimiento y el respeto de las garantías procesales como límite a las actuaciones de poder y dentro de un marco que se consolida con un juicio oral, público, con inmediación, contradicción y concentración, en el que "el juez únicamente puede dictar la sentencia con base en las pruebas practicadas en el juicio" (Urbano, 2008, p. 13).

De acuerdo con el artículo 288 de la Ley 906 de 2004 y la doctrina imperante (Espitia, 2006, p. 123; Ramírez, 2010, p. 266), corresponde a la fiscalía al momento de comunicar o formular los cargos no solo referir los hechos en que se funda la vinculación formal a la investigación de la persona, sino también su correcta adecuación jurídica; en este acto de "comunicación", la ley autoriza al ente fiscal para que entere al imputado de la posibilidad que tiene de allanarse y de la rebaja que por ese acto se le reconoce, la cual varía según se trate de una captura en flagrancia o no. Si la persona imputada, previamente las amonestaciones y claridades que le hace la judicatura, entre ellas, renunciar a un juicio oral, público y contradictorio, decide aceptar los cargos se entiende "que lo actuado es suficiente como acusación" (L. 906/2004, art. 293); se trata, pues, de un acto en el que el allanamiento o alegación de culpabilidad -plea guilty- (Guerrero, 2011) es producto de la determinación unilateral del imputado de asumir los cargos que le han sido enrostrados por parte de la Fiscalía General de la Nación.

No obstante, un tratamiento distinto le dio al instituto la Sala de Casación Penal de la Corte Suprema de Justicia al abordar la aplicación favorable de la rebaja del artículo 351 de la Ley 906 de 2004 prevista para los allanamientos en casos tramitados bajo la Ley 600 de 2000 en los que el investigado se acogía a sentencia anticipada, pues aseguró que existía una diferencia radical entre la aceptación de responsabilidad bajo la asidua ley mencionada y la Ley 906 de 2004, al referir que esta última se sustentaba en una negoción o convenio entre la fiscalía y el imputado o acusado, dentro de la cual se valoraba el monto de la rebaja de la pena (Sentencia de agosto 23 de 2005, Radicado 21954, CSJ). Esta posición, a pesar del salvamento de voto de algunos magistrados, finalmente fue reformulada por el Alto Tribunal, pues concluyó que la aceptación de responsabilidad unilateral -o allanamiento a cargos- tramitado bajo la Ley 906 de 2004, no está precedida de convenio o negociación entre la fiscalía y el imputado o acusado, sino que se trata -como su nombre lo indica- de un acto unilateral, voluntario y libre del último mencionado, por lo que la fijación de la pena precedida de la rebaja depende solo del juez de conocimiento dentro del marco de movilidad que le confiere el ordenamiento jurídico; en virtud de lo aludido terminó por señalar que sí era viable aplicar entonces el principio de favorabilidad entre las normas procesales enunciadas (Sentencia de abril 8 de 2008, Radicado 25306, CSJ).

Como se ve, pues, en sus inicios el alto tribunal de cierre de la jurisdicción ordinaria penal, dio un tratamiento a los "allanamientos" que no correspondía con la naturaleza de éstos; al concebirlos como una especie de acuerdo, generaba un problema mayor orientado por el cuestionamiento de si ese "acuerdo" podía ser reversado sin la anuencia de la fiscalía. Dicho de otra manera, la posición errática 
de la Corte Suprema de Justicia, Sala de Casación Penal, significaba que el "allanamiento" además de ser un acto de ambas partes y no exclusivo del imputado o acusado (entendimiento genuino), se asociaba a una negociación de la que difícilmente podía zafarse aquél. Así las cosas, la solución que se propone en torno al sentido del instrumento jurídico del allanamiento, parece estar acorde con lo previsto en el literal $l$ del artículo $8^{\circ}$ de la Ley 906 de 2004 que autoriza al imputado "Renunciar a los derechos contemplados en los literales b) y k) siempre y cuando se trate de una manifestación libre, consciente, voluntaria y debidamente informada"; también, con los artículos 131, 283, 293, 351, 353, 356 numeral 5 de la Ley 906 de 2004.

\section{Fases del proceso penal en las que procede el "allanamiento" a cargos.}

El primer momento procesal con el que cuenta el indiciado para aceptar unilateralmente los cargos penales enrostrados por la Fiscalía General de la Nación, es la audiencia de formulación de imputación y hasta antes de formularse acusación si aspira a obtener una rebaja de hasta la mitad de la pena a imponer, siempre que no se trate de una captura en flagrancia (L. 906/2004, arts. 301 y 351). En efecto, acorde con la Ley 906 de 2004, el epilogo de la comunicación de cargos (imputación) está marcado por la obligación que tiene la fiscalía de indicar la "posibilidad del investigado de allanarse a la imputación y a obtener rebaja de pena de conformidad con el artículo 351" (art. 288, N. ${ }^{\circ}$ 3). A su turno, el artículo 293 idem señala que "si el imputado, por iniciativa propia o por acuerdo con la Fiscalía acepta la imputación, se entenderá que lo actuado es suficiente como acusación"; esto quiere decir que, de presentarse el primero de los eventos, a partir de la aceptación de culpabilidad declarada ante el juez de control de garantías el imputado pasa a ser acusado y, por ende, queda a la espera de que el juez de conocimiento profiera en su contra la sentencia respectiva, previo traslado del artículo 447 idem.

La mala redacción del artículo fácilmente puede conducir a varias interpretaciones, a saber: una, que la aceptación de culpabilidad puede ser transada en la audiencia preliminar con la fiscalía (tesis defendida por la Corte Suprema de Justicia en un inicio, como ya se vio), esta apreciación se refuerza con la deficiente redacción del artículo 351 al disponer que "la aceptación de los cargos determinados en la audiencia de formulación de la imputación, comporta una rebaja hasta de la mitad de la pena imponible, acuerdo que se consignará en el escrito de acusación" (L. 906/2004); sin embargo, la delimitación conceptual que en torno a la figura se hizo en párrafos anteriores, permite superar esta primera impertinencia; $y$, otra, que el fiscal del caso no estaría obligado a presentar nuevamente acusación ante el juez de conocimiento, pues lo actuado en la diligencia de imputación es suficiente como acusación" por lo que correspondería a este funcionario correr el traslado del artículo 447, individualizar la pena y dictar sentencia. Desde luego, la última de las interpretaciones es inconstitucional en la medida en que pone en serios aprietos la estructura del sistema penal acusatorio, pues la acusación debe promoverse única y exclusivamente ante el juez de conocimiento aun en los supuestos de procedimientos abreviados ("allanamientos" y preacuerdos). 
Ahora bien, en este interregno, esto es, entre la formulación de imputación y la audiencia de formulación de acusación, es conveniente preguntarse si resulta válido que el investigado a pesar de haber aceptado los cargos en la audiencia preliminar pueda retractarse. El punto a tratar, guarda estrecha relación con lo planteado en este artículo, pues sólo es posible hablar de la retractación a los cargos atribuidos si, previamente, existe aceptación de los mismos por parte del imputado. Aunque esto parezca obvio, este aspecto es trascedente, dado que la Sala de Casación Penal luego de considerar el problema planteado a inicio del párrafo, negó la posibilidad del retracto; sin embargo, la hipótesis que aquí se defiende, en contraposición a lo expuesto por el máximo Tribunal, es afirmativa, en contraposición al criterio de la jurisprudencia penal. Sobre estos se volverá más adelante.

Los siguientes momentos procesales con los que cuenta el procesado para aceptar unilateralmente los cargos son: la audiencia preparatoria (art. 365, N. ${ }^{\circ}$ 5), evento en el cual la rebaja se reduce a una tercera parte de la pena a imponer. Y, la última oportunidad es en la alegación inicial del juicio oral (art. 367); en éstos últimos escenarios, no resulta oportuno plantarse el anterior cuestionamiento, dado que, al contrario de lo que sucede en la audiencia preliminar, los cargos han sido claramente definidos fáctica, jurídica y probatoriamente, de modo que el juez de conocimiento tiene a su disposición todos los elementos de prueba para aceptar el "allanamiento" a cargos. Es decir, no se trata de escenarios ligeros como sí acontece con la audiencia de formulación de imputación, en donde la fiscalía con marcada influencia del sistema adversarial estadounidense no está siquiera obligada a descubrir elementos de pruebas (Sánchez, 2016); en esta fase es probable que se cometan errores en la comunicación de cargos (distintos a los vicios en el consentimiento y la violación de garantías fundamentales), razones que sumadas a otras legitiman la retractación, esto es, la revocación expresa por parte del imputado del consentimiento de culpabilidad trasmitido al juez de control de garantías. Ahora bien, es necesario hacer una precisión: si bien es cierto que se han indicado los momentos procesales en los cuales el procesado puede aceptar unilateralmente los cargos a cambio de un beneficio punitivo, nada obsta para que, iniciada la práctica probatoria, él acepte los cargos formulados en la acusación. Nada se opone a ello. Si bien es cierto no existe un momento procesal precisamente demarcado para tal fin, el mismo procesado puede, solo o a través de su defensor, plantearle al juez de conocimiento su intención de evitar un mayor avance del proceso. Por supuesto, ningún descuento, en un inicio, podría recibir, pero nada impide que, a cambio de evitar mayores avances el proceso, el acusado se allane a los cargos. Al respecto, recientemente la doctrina especializada (Saray, 2017bis, p. 309) reconoce, frente a la aceptación negociada, que "el procesado, asesorado por su abogado defensor, puede aceptar los cargos formulados en la acusación de manera consensuada con el fiscal en la fase procesal indicada anteriormente, caso en el cual el legislador no previó beneficio, lo que no obsta para que el negocio jurídico en estas condiciones surta sus efectos, si de tal situación se le ha enterado con suficiencia al procesado, el cual obtendrá una sentencia de condena sin rebaja de pena alguna". 


\section{Entre la retractación y la nulidad en la aceptación de responsabilidad unilateral o "allanamientos" puros y simples: ¿Es posible o no el retracto efectivo en la Ley 906 de 2004?}

El derecho o beneficio de retracto es una figura que se encuentra regulada en el artículo 1971 del Código Civil Colombiano, y, a través de ésta, se permite en el contrato de cesión de derechos litigiosos al cedente o a un tercero ajeno a dicho negocio jurídico (Sentencia de agosto seis de 2009, Radicado 17256, C.E.) retraer para sí el negocio cedido; así mismo, conforme a la Ley 1480 de 2011, el derecho de retracto se presenta "como una forma de terminación unilateral de los contratos, sin necesidad de justa causa, motivación o consideración por los intereses de los empresarios o agentes del mercado" (Pabón \& Mora, 2014, p. 67).

Mírese, entonces, como el retracto es una decisión de carácter unilateral que toma la persona para reversar o terminar el contrato. En el procedimiento penal colombiano, más concretamente en los "allanamiento" simples (aceptación unilateral de cargos) y en los preacuerdos (aceptación negociada de los cargos), la ley reconoce a las partes por igual el derecho de retracto, de modo que, a través de él puedan desdecir lo que negociaron o el imputado o acusado retraerse del cargo que aceptó, no obstante, la interpretación que al respecto ha dado la jurisprudencia de la Sala de Casación Penal de la Corte Suprema de Justicia ha sido ambigua. Miremos. La primera en pronunciarse sobre este tópico fue la Corte Constitucional; el alto tribunal de cierre de la jurisdicción constitucional dijo:

[U]na vez realizada la manifestación de voluntad por parte del imputado, en forma libre, espontánea, informada y con la asistencia del defensor, de modo que sean visibles su seriedad y credibilidad, no sería razonable que el legislador permitiera que aquel se retractara de la misma, sin justificación válida y con menoscabo de la eficacia del procedimiento aplicable y, más ampliamente, con detrimento de la administración de justicia, como lo pretende el demandante. En este orden de ideas, la garantía constitucional del derecho de defensa del imputado no puede traducirse en que la terminación anticipada del proceso en virtud de la aceptación de responsabilidad por parte de aquel, con o sin acuerdo con la Fiscalía, quede condicionada a nuevas manifestaciones de voluntad del mismo, de modo que la primera manifestación sería visiblemente precaria y a la postre el proceso no podría terminar anticipadamente, eliminando así la entidad y la utilidad de dicho mecanismo, que es esencial dentro del nuevo procedimiento, y contrariando también el principio de seguridad jurídica, de singular relevancia en un Estado de Derecho (Sentencia C-1195 de 2005, CConst.).

Conforme a lo anterior, la Corte Constitucional consideró ajustada a la Carta Política la expresión "sin que a partir de entonces sea posible la retractación de alguno de los intervinientes" contenida en el art. 293 de la Ley 906 de 2004. A pesar de ello, véase que la misma Corte admite el retracto en tanto éste aparezca justificado, es decir, al contemplar tal posibilidad, es claro que la aceptación unilateral del cargo no se cierra en el preciso instante en que ella es ratificada ante el juez de control de garantías, pues el imputado podrá entre este momento y la acusación desdecir de tal allanamiento, empero, siempre que lo justifique. Esto es, se trata de un retracto condicionado no por la constatación de vicios en el consentimiento 
ni por violación de garantía fundamentales, pues en uno de tales eventos, lo que procede es la nulidad del allanamiento, bien de oficio ora a petición de parte.

Adicional a lo dicho, la Corte Constitucional funda la irretractabilidad por fuera de los supuestos que sean debidamente justificados en la salvaguarda de los principios de seguridad jurídica y adecuada administración de la justicia, es decir, cuando el retracto se autoriza para ser ejercido en cualquier momento y sin justificación alguna se desdice la seriedad del procedimiento penal. Lo que no se tiene en cuenta por parte de la jurisprudencia es la ambigüedad con la que se ha tratado el retracto, pues en algunas oportunidades se asimila y asociado con el retracto civil y a un ejercicio libre de la voluntad y, en otras, se condiciona a la vigencia de principios que, si bien son importantes, no tienen el peso que sí conservan otros como la no autoincriminación y la presunción de inocencia.

Por su parte, la Sala de Casación Penal de la Corte Suprema de Justicia, sin alejarse de lo atrás referido, indicó que la retractación pura y simple, luego de aprobado por el juez -de control de garantías o de conocimiento- el allanamiento o aceptación unilateral, no resulta posible, sin embargo, de acreditarse vicios en el consentimiento o, vulneración de garantías fundamentales, en cuyo caso es viable solicitar la ineficacia de acto de aceptación de responsabilidad, es decir, lo procedente es implorar la nulidad (Sentencia de febrero 13 de 2013, Radicado 40053, CSJ).

La conclusión a la que arriba la Sala en éste pronunciamiento es cierta, pues admite que la retractación no es posible si se descubre, inclusive oficiosamente por el juez de conocimiento y no sólo a petición de parte como se expresa en el pronunciamiento, que la aceptación unilateral de culpabilidad generada en la audiencia preliminar estuvo precedida de un vicio en el consentimiento o hubo una violación de garantías fundamentales; en éste supuesto, lo que procede es la nulidad del acto de allanamiento (Sentencia AP830 de febrero 26 de 2014, Radicado 34699, CSJ) y por simple lógica nadie puede retractarse de algo que no existe jurídicamente, es decir, que no lo vincula. Entonces, lo que se percibe del pronunciamiento, es que no existe tal posibilidad de retracto, pues las dos irregularidades que contempla el parágrafo del artículo 293 del Código de Procedimiento Penal, no son más que motivos generadores de la nulidad del allanamiento simple (también del preacuerdo).

No obstante, la misma Sala (Sentencias de mayo 10 de 2006, Radicado: 25248, CSJ; de febrero 21 de 2007, Radicado: 26587, CSJ; de julio 27 de 2011, Radicado: 35860, CSJ; de diciembre 7 de 2011, Radicado: 36367, CSJ; de marzo 23 de 2011, Radicado: 35771, CSJ; de noviembre 20 de 2013, Radicado 39834, CSJ; de febrero 13 de 2013, Radicado: 39707, CSJ) de forma errática ha prohijado ampliamente la tesis de que la retractación sólo es posible en cuanto se advierte un vicio en el consentimiento o la violación de garantías fundamentales, cuestiones ambas, que vistas desde la perspectiva del derecho civil (en especial la primera) y del derecho procesal penal, no son una retractación sino causales de nulidad (Saray, 2017; Sentencia de agosto 28 de 2013, Radicado: 40026, CSJ). 
Así las cosas, el parágrafo del artículo 293 de la Ley 906 de 2004 es una proposición incoherente que condiciona la retractación a la demostración de un vicio en el consentimiento o a la violación de garantías fundamentales cuando, en estricto sentido jurídico, se sabe que ello genera la nulidad del acto unilateral o bilateral de aceptación de culpabilidad. Además, la retractación por definición es un acto unilateral, un derecho reconocido en la ley civil que en cualquier momento puede hacerlo valer la persona para deshacer el contrato. En la ley procesal penal, pareciera, no existe tal derecho, o si lo hay se le ha comprendido erróneamente por la jurisprudencia.

\section{La retractación al "allanamiento" a cargos en la jurisprudencia de la Sala de Casación Penal de la Corte Suprema de Justicia}

Como habrá podido haberse notado a lo largo de este escrito en torno a la retractabilidad la Sala de Casación Penal de la Corte Suprema de Justicia ha fluctuado, en términos generales, no sólo en cuanto a la procedencia sino también en torno a los motivos que habilitan el ejercicio de este derecho. En este apartado, solo se discute sobre las distintas líneas jurisprudenciales trazadas por el alto tribunal en torno al retracto en los "allanamientos".

\section{Primera postura jurisprudencial: no hay lugar a la retractación.}

En decisión del diez de mayo de 2006, con ponencia del magistrado Mauro Solarte Portilla, la Sala de Casación Penal de la Corte Suprema de Justicia señaló expresamente que la aceptación de culpabilidad unilateral o bilateral está cobijada por el principio de irretractabilidad, con lo cual se prohíbe una discusión futura en torno a los términos en que se produjo el "allanamiento":

[L]a limitación a la posibilidad de discutir o controvertir los términos de las aceptaciones o acuerdos, ha sido normativamente regulada por la ley a través de lo que la doctrina y la jurisprudencia ha denominado principio de irretractabilidad, que comporta, precisamente, la prohibición de desconocer el convenio realizado, ya en forma directa, como cuando se hace expresa manifestación de deshacer el convenio, o de manera indirecta, como cuando a futuro se discuten expresa o veladamente sus términos. Por los mismos motivos, es decir, cuando el proceso abreviado se adelanta con fundamento en una aceptación o acuerdo ilegal, o con quebrantamiento de las garantías fundamentales, los sujetos procesales están legitimados para buscar su invalidación en las instancias o en casación, pero estas nociones difieren sustancialmente del concepto de retractación, que implica, como ya se dejó consignado, deshacer el acuerdo, arrepentirse de su realización, desconocer lo pactado, cuestionar sus términos, ejercicio que no es posible efectuar cuando su legalidad ha sido verificada y la sentencia dictada (Sentencia de mayo 10 de 2006, Radicado: 25248, CSJ).

El mismo criterio fue reiterado por el alto tribunal en decisión 26645 del once de abril de 2007; dicha postura fue reproducida de forma literal en los siguientes proveídos de que dan cuenta estos radicados: 28161 del diez de octubre de 2007; 28433 del 24 de octubre de 2007; 29180 del 31 de marzo de 2008; 28772 del 30 de enero de 2008. En este último proveído, se sostuvo que el sometimiento del procesado a 
través de los mecanismos propios de la justicia premial, entre ellos el "allanamiento" a cargos, tiene como consecuencia invariable la irretractabilidad (Sentencia de enero 30 de 2008, Radicado: 28772, CSJ).

En épocas más recientes, la Sala de Casación ha mantenido el criterio de la irretractabilidad en los allanamientos en los siguientes pronunciamientos: radicados 35860 del 27 de julio de 2011; 36367 del 7 de diciembre de 2011; 39707 del 13 de febrero de 2013; en ésta última providencia sostuvo que el principio se deriva de la lealtad procesal contemplada en el artículo 12 de la Ley 906 de 2004, pues no resulta posible que un compromiso de tal envergadura -aceptación de responsabilidad-sea desconocido mediante un acto puro y simple (Sentencia de febrero 13 de 2013 Radicado: 39707, CSJ).

Con base en la decisión que se acaba de citar, el alto tribunal forjó su postura en igual sentido en los pronunciamientos contenidos dentro de los radicados 40026 del 28 de agosto de 2013; 39566 del 28 de agosto de 2013; 41419 del 28 de agosto de 2013; 41295 del 28 de agosto de 2013; 45333 del 25 de febrero de 2015. En todo caso, debe decirse que con la historiografía jurisprudencial que se ha hecho queda constatada una línea respecto a la irretractabilidad de los allanamientos, salvo que se advierta la presencia de uno de los eventos previstos en el artículo 293 del CPP. Los fundamentos que en torno a la prohibición de retractación ha señalado la jurisprudencia son muy variados, pues en unas decisiones (las primeras) la justificación estuvo dada por la larga tradición de la irretractabilidad en el proceso penal abreviado (sentencia anticipada, acuerdos, allanamientos, preacuerdos y negociaciones); en otras, ha acudido a criterios principialísticos, verbigracia, la lealtad procesal, la seguridad jurídica (Sentencia C-1195 de 2005, CConst.; Sentencia de noviembre 20 de 2013, Radicado: 39834, CSJ).

\section{Segunda postura jurisprudencial: sí hay lugar a la retractación.}

Una segunda línea de pensamiento ha sido la trazada en la sentencia del 21 de marzo de 2012; en ésta se dijo:

Cuando se acude a la definición natural del término y a la forma como es tratado en el artículo 293 de la Ley 906 de 2004, necesariamente se debe concluir, por esencia, que el retracto informa de la posibilidad o facultad, derivada de la simple voluntad, de desdecirse de una actuación o manifestación (Sentencia de marzo 21 de 2012, Radicado: 38500, CSJ).

Por supuesto, si bien es cierto que en el pronunciamiento citado la Sala de Casación Penal hacía referencia a los preacuerdos no cabe duda de que al indicar el sentido prístino del artículo 293 del CPP, éste, ha de entenderse, también es predicable de los allanamientos puros y simples -o aceptación de responsabilidad unilateral- puesto que el artículo en términos generales regula el procedimiento a seguir "en caso de aceptación de la imputación", la cual se sabe bien puede generarse por iniciativa propia del imputado (aceptación unilateral) o por acuerdo o negociación con la fiscalía. 
Ahora bien, la posibilidad de dejar sin efectos -por vía de la retractación- el "allanamiento" quedó autorizada por la Corte Suprema de Justicia en pronunciamiento del 30 de mayo de 2012:

[c]uando el acto de aceptación a los cargos se produce en la audiencia preliminar de formulación de imputación ante el juez de control de garantías, un interregno procesal comprendido entre este acto y el posterior por medio del cual el juez de conocimiento le imparte aprobación a la manifestación durante el cual, según el claro entendimiento del inciso segundo del artículo 293 del estatuto procesal es viable la retractación en su expresión pura y simple, esto es, sin que sea preciso invocar justificación alguna (Sentencia de mayo 30 de 2012, Radicado: 37668, CSJ).

La postura mayoritaria, como habrá podido notarse, se inclina por la primera de las tesis, a saber, que no es válida la retractación en los "allanamientos"; sin embargo, los dos pronunciamientos citados tienen bases teóricas interesantes en torno al principio de autonomía que gobierna los actos de aceptación unilateral de la culpabilidad. A pesar de tan abrumadora línea, también se ha admitido la retractación cuando el peticionario para convencer al juez de conocimiento demuestre fáctica y probatoriamente el motivo del retracto (Saray, 2017bis).

\section{¿Debe admitirse la retractación?}

La tesis aquí defendida parte del supuesto según el cual en el interregno existente entre la formulación de imputación y la audiencia de formulación de acusación debe permitírsele al imputado retractarse acorde con las razones que a continuación pasan a esbozarse.

\section{No existe conocimiento pleno y certeza sobre los elementos de prueba que soportan los cargos y la participación penal aceptada.}

Cuando el incriminado decide aceptar su responsabilidad en procura de obtener un descuento punitivo, actúa así porque ha sopesado directamente su grado de compromiso frente al delito endilgado y la conveniencia de asumir la responsabilidad del mismo. Sin embargo, la valoración del imputado para decidir si acepta o no los cargos comunicados en ese estadio procesal, se despliega sin que necesariamente conozca los elementos materiales probatorios con base en los cuales el órgano de persecución penal sustenta la imputación, es más el fiscal ha desplegado una mínima actividad de investigación, sin embargo ello "sujeta al juez/la jueza de conocimiento a la imposición de una pena, sin pasar por el debate probatorio" (Guerrero, 2017); por ello esa es una razón suficiente para que la doctrina lance innumerables críticas a dicha postura.

A título de ejemplo, el profesor Del Río (2008) estima que en temas como las negociaciones -lo cual también puede aplicarse a la aceptación unilateral de responsabilidad-, se ejerce una desproporcionada coacción sobre el procesado, al menos psicológica, con lo cual se pisotea el principio de presunción de inocencia; por ejemplo, a través de mecanismos como la amenaza de inflar los cargos para lograr la autoincriminación. Además, la relación entre el procesado y quien atri- 
buye la responsabilidad es claramente desigual en tanto que este último tiene en sus manos su libertad (Galain, 2005), pues cuenta con la posibilidad de solicitar su restricción.

Es decir, en la primera salida procesal existe un veto probatorio que impide al imputado tener certeza sobre el hecho punible atribuido y la participación en éste; este obstáculo se encuentra autorizado por la ley procesal penal en tanto el artículo 287 habilita a la fiscalía para que no descubra en la comunicación de los cargos elementos materiales probatorios. Es decir, a juicio del legislador resulta válido que la persona se declare responsable penalmente sin auscultar el material probatorio que respalda lo que se le endilga y, aunque en los manuales de la Fiscalía General de la Nación se recomienda a los fiscales actuar con prudencia en este estadio procesal -pues la comunicación de los cargos "exige una carga probatoria suficiente que permita inferir razonablemente que una persona es autora o partícipe de la conducta que se investiga" (Vanegas, 2007, p. 53)-, en la práctica judicial se evidencian falencias referidas a la imputación de los cargos y a los elementos materiales probatorias que sirven de soporte.

Ahora bien, si se sigue la literalidad del artículo 293 de la Ley 906 de 2004, en el que claramente se establece que "Si el imputado, por iniciativa propia [...] acepta la imputación, se entenderá que lo actuado es suficiente como acusación", debe decirse que en el trámite abreviado del allanamiento el imputado debe tener conocimiento de todos los elementos materiales probatorios y la fiscalía está obligada a descubrirlos con el objeto de evitar fallas en la aceptación de culpabilidad; de lo contrario, un allanamiento proferido con semejantes vetos, legítima al imputado para retractarse de la totalidad de los cargos o parcialmente cuando advierta en la acusación abreviada que los delitos aceptados no tienen fundamento probatorio. Recuérdese que ha sido criterio reiterado de la jurisprudencia constitucional y ordinaria, señalar que el derecho al debido proceso y de defensa, están estrechamente comprometidos con el descubrimiento probatorio que pretende garantizar la transparencia del juicio penal o "fair trial", por eso pensar que en los "allanamientos" puros y simples o aceptación de responsabilidad unilateral (también los preacuerdos) tales garantías se relativizan, resulta contrario a la Constitución Política. Respecto a lo considerado la jurisprudencia ha dicho que "en ese contexto, el descubrimiento probatorio está vinculado indisolublemente al debido proceso y al derecho a la defensa, en razón a la trascendental incidencia de dicho instituto en el desarrollo de la actividad de cada una de las partes" (Sentencia AP2564 de mayo 20 de 2015, Radicado: 45667, CSJ).

En igual sentido, se ha afirmado que:

De igual manera, el último inciso del artículo 250 de la Constitución Política modificado por el artículo $2^{\circ}$ del Acto Legislativo 03 de 2002 que introdujo el sistema acusatorio, es claro al señalar que "En el evento de presentarse escrito de acusación, el Fiscal General o sus delegados deberán suministrar, por conducto del juez de conocimiento, todos los elementos probatorios e informaciones de que tenga noticia incluidos los que le sean favorables al procesado"; la regla transcrita, clarifica aún 
más lo que aquí se ha querido significar. En efecto, si el allanamiento hace las veces de acusación y una vez éste se profiere, la fiscalía al presentar ante el juez de conocimiento el escrito contentivo de los cargos aceptados, debe dar alcance al imputado y a su defensor de los elementos materiales probatorios con los que sostuvo la imputación (claro, en caso de que no haya hecho el descubrimiento total en la audiencia preliminar); una deficiencia en tal proceder, por ejemplo, justifica la retractación en éste interregno o, en el supuesto contrario, esto es que en la audiencia ante el juez de conocimiento permita el acceso previo de todo el arsenal probatorio y el imputado junto con el defensor advierta que no son meritorios para respaldar los cargos imputados o que hubo un error en éstos, también resulta legítimo permitirse el retracto.

Con mayor razón si la jurisprudencia constitucional ha dicho:

[A]unque en esta audiencia [formulación de imputación] el presunto infractor de la ley penal no puede controvertir ni modificar los términos de la imputación, tiene la posibilidad de hacerlo durante todo el procedimiento penal [inclúyase aquí los trámites abreviados como el allanamiento]; es decir, la defensa material no se ejerce en dicha audiencia, sino justamente a partir de ella (Sentencia C-303 de 2013, CConst.).

Lo anterior, es decir la ligereza con que se hace la formulación de imputación y el propósito efectista que se persigue por parte de la fiscalía con los mecanismos de terminación abreviada del proceso, a juicio de Del Moral, tienen implícito:

[T]odo sistema de convenios en el proceso penal arrastra el riesgo cierto de crear una red en la que queden atrapados algunos inocentes cuya culpabilidad no hubiera podido acreditarse en un juicio normal: el peligro de auténticos chantajes legales o concesiones por temor a un mal sólo probable, pero mayor que el cierto que se ofrece a cambio, es algo sobre lo que se debiera reflexionar más (2008, p. 7).

En la práctica, el procesado no siempre asume la responsabilidad en razón a que sopesó su compromiso delictual dada la comunicación de cargos que se le realiza; en algunas ocasiones, su manifestación no es más que la exteriorización de una coacción impropia devenida del temor que implica enfrentarse a una sanción drástica, pues ello no es otra cosa que "una amable invitación para aceptar la responsabilidad penal lo más pronto posible y lograr la rebaja punitiva que ofrece el ordenamiento" (Molina, 2012, p. 357) por lo cual resulta válido dudar de la libertad y espontaneidad de la decisión del procesado. En un sentido similar Guerrero apunta:

[L]o que sí ha demostrado la práctica es que el fiscal puede ir a la audiencia de imputación con unos cargos que trascienden lo acaecido en la realidad y que per se tienen entidad para incidir en la voluntad del investigado por la gravedad de los hechos que endilga la Fiscalía (2011, p. 504).

Una situación como la descrita debería ser tenida en cuenta a la hora de cerrársele la puerta a la retractación en el interregno de la formulación de imputación y la acusación, pues en la praxis judicial se evidencia que los fiscales inflan los cargos y someten al imputado a una presión indirecta o directa cuando le piden que acepte los cargos a cambio de no solicitarle medida de aseguramiento, por ejemplo. 
En el derecho norteamericano este tipo de supuestos ha pretendido controlarse mediante el factual basis of the plea (Guerrero, 2011, p. 504), esto es, que a pesar de la aceptación unilateral (o acordada) de la responsabilidad penal compete al juez verificar el supuesto factual que condujo al allanamiento o, en palabras de Guerrero, "si el juez alberga dudas sobre la culpabilidad de la persona que se somete al procedimiento de delegación entonces debe llegar a la convicción de que aquel es responsable sobre la base fáctica del hecho alegado" (2011, p. 505). De esta manera, la solución que se propone implica que el juez no queda completamente obligado a dictar la sentencia como contrariamente lo sugiere Damián (2001) con respecto al allanamiento en los procesos civiles (en la práctica judicial algunos jueces lo conciben así). El factual basis of the plea, permite que el juez de conocimiento no pase por alto las deficiencias que pueda presentar la imputación y sobre la cual el investigado aceptó los cargos y relegó al Estado de probar en un juicio público la culpabilidad que le atribuye.

\section{La retractación no está sometida a condición alguna.}

En su prístino sentido retractarse no es más que desconocer los términos de lo aceptado o convenido de forma unilateral frente a acto cualquiera, en este caso la aceptación de la responsabilidad penal. En el Código de Procedimiento Penal, más exactamente en el artículo 293, no existe condicionante alguna que limite el ejercicio del derecho de retracto, aunque otra haya sido la interpretación de la jurisprudencia penal al tratar la figura en los albores de la Ley 906 de 2004. Dicho de otra manera, lo que la norma establece no son más que causales que dan origen a la nulidad del "allanamiento" a cargos o aceptación unilateral de la responsabilidad (también del acuerdo) cuando uno de estos dos eventos se advierta: vicios en el conocimiento los cuales, exceptuado el error de derecho (Sentencia C-993 de 2006, CConst.), generan la nulidad y; la violación de garantías constitucionales (falta de defensa técnica, por ejemplo).

De manera que si la acción de retracto no está condicionada por la ley, ¿por qué, entonces, no permitirse en el interregno de la formulación de imputación y la acusación abreviada en los términos de la sentencia 37668 del 30 de mayo de 2012? La retractación de la admisión de culpabilidad, puede decirse emerge como un punto medio de protección de garantías procesales dentro de la balanza de contrapesos; no obstante, pocas líneas desde la doctrina foránea e interna se han dedicado a reflexionar sobre el tema.

Ahora bien, el argumento que la jurisprudencia penal ofrece para negar tal posibilidad no comporta otra cosa que privilegiar principios de poco peso (seguridad jurídica, eficiencia de la administración de justicia, etc.), frente a otros de un peso superior (no autoincriminación, presunción de inocencia, etc.); el retracto, si se acepta la tesis que aboga por la ausencia de norma que lo prohíba en el proceso penal, en últimas, asegura las garantías fundamentales que debe tener todo procedimiento que se repute democrático. Insistir en la irrectratabilidad sin que exista base jurídica para ello implica una relativización de estas garantías, pues como se 
ha dicho a lo largo de este trabajo el parágrafo del artículo 293 de la Ley 906 de 2004 reúne condiciones que conducen a la ineficacia del allanamiento o a la nulidad de éste, y no pueden interpretarse como condicionantes para que el imputado reverse la aceptación de los cargos en la audiencia donde se formaliza la acusación “abreviada".

\section{El juez de garantías no es quien debe decidir la responsabilidad penal en el trámite abreviado.}

Justamente, la redacción del precepto normativo dejó abierta la puerta para que el imputado pueda retractarse de la aceptación de responsabilidad si tal cosa ocurre en la audiencia de formulación de imputación y antes de ser validada por el juez de conocimiento, pues en ese específico evento la manifestación se produce con anterioridad al momento en el cual el juez de conocimiento haya verificado si la misma fue libre, voluntaria y espontánea, con lo que producida con anterioridad la retractación no entraría dentro de la prohibición expresa que contempla la norma.

Por ello, vale recordar que si el incriminado decide aceptar cargos en la audiencia de formulación de imputación la manifestación en tal sentido la realiza ante el juez de control de garantías, distinto al juez de conocimiento que deberá proferir sentencia ante la aceptación de responsabilidad. El primero de los jueces no ausculta los hechos y los elementos de pruebas, tampoco puede exigir su conocimiento o descubrimiento en tanto la fiscalía por mandato legal no está obligada a develarlos en la audiencia preliminar (L. 906/2004, art. 288). Esto es trascedente considerarlo, pues en tales condiciones no podría justificarse que el filtro que hace el juez de garantías, quien no puede intervenir la tipificación y a lo sumo recomienda su corrección, resulta suficiente para asumir que la aceptación de culpabilidad debe mantenerse salvo que se presente uno de los supuestos del parágrafo del artículo 293 de la Ley 906 de 2004. Siguiendo esta hermenéutica, y ante los riesgos que se corren de una comunicación de cargos "imperfecta", la retractación busca que un yerro de esa magnitud se corrija ante el juez de conocimiento quien -en últimas- es el verdadero auscultador de los medios de prueba y de los cargos imputados y aceptados.

Entonces, debido a la responsabilidad encomendada es permitido pensar que el legislador le confió al juez de conocimiento la tarea adicional de verificar la validez del trámite en el que se generó el allanamiento a cargos o aceptación unilateral de la responsabilidad, pues aunque haya podido generarse sin que se hubiese descubierto elemento material probatorio alguno de encontrar acreditados los presupuestos mínimos del acto, no habría lugar a la retractación y deberá dictar el fallo condenatorio correspondiente; no obstante, en el interregno anterior, es decir en el momento previo a la verificación, resulta viable la retractación como expresión del incriminado, sobre todo si llega a advertirse que los elementos de pruebas no soportan la culpabilidad aceptada, ora, por qué no pensar también que a posteriori surge un elemento material probatorio que desdice el cargo o algunas de sus circunstancias agravantes o la inferencia razonable de autoría y participación. 


\section{La sentencia C-1195 de 2005 no cerró del todo la posibilidad de la retractación.}

En efecto, dicho proveído al referirse a la constitucionalidad del artículo 293 juzgó poco "razonable que el legislador permitiera que aquel se retractara de la misma, sin justificación válida" (Sentencia C-1195 de 2005, CConst.); obviamente, ésta justificación no tiene nada que ver con la demostración de vicios en el consentimiento o la violación de garantías dado que son causales de nulidad de la aceptación de culpabilidad sino, más bien, está orientada a permitir que el retracto se genere no por capricho del imputado -pues una tal interpretación restaría seriedad al instituto del "allanamiento" a cargos- sino cuando sobrevenga una razón como las anotadas en precedencia. Acaso: ¿la ausencia de elementos de pruebas que soporten los cargos imputados y aceptados, no justifican la retractación? ¿La ubicación de nuevos elementos materiales probatorios por parte del imputado o su defensa que desdiga los cargos y sus circunstancias agravantes en su totalidad o parcialmente, no justifican la retractación?

\section{Conclusiones}

Abarcados en su totalidad los temas que se propusieron aspira este trabajo a abrir el debate necesario sobre la posibilidad del incriminado de retractarse de la manifestación a través de la cual aceptó la responsabilidad penal dentro de la audiencia de formulación de imputación, previa a la verificación del allanamiento por el juez de conocimiento, en el marco del proceso penal colombiano, a cuyo efecto se considera prudente realizar las siguientes reflexiones:

De entrada, es importante recordar que la aceptación de responsabilidad penal permite culminar de manera anticipada el proceso sin necesidad de agotar las etapas ordinarias que cierran con un juicio en el que se practica la prueba, se debate la ocurrencia del hecho tildado de delictivo y la responsabilidad penal del acusado. Se trata, ni más ni menos, de la posibilidad de acudir al derecho penal abreviado con una manifestación de la justicia premial.

Precisamente, en el sistema vigente para condenar a una persona dentro del trámite ordinario penal el juez requiere de un conocimiento más allá de toda duda acerca de la materialidad delito y de la responsabilidad penal del acusado, fundado en pruebas debatidas en el interior del juicio. Pero si se culmina de forma anticipada el proceso, vía aceptación de responsabilidad, el estándar probatorio para condenar disminuye puesto que al no existir juicio no hay posibilidad de controvertir las pruebas que en desarrollo del mismo se habrían podido practicar, lo cual supone que la sentencia condenatoria termina soportándose en el allanamiento a cargos y los elementos materiales probatorios recolectados por el órgano de persecución penal en una etapa primaria del proceso, sin que los mismos hubiesen sido objeto de debate y controversia.

Desde la entrada en vigencia de la Ley 906 de 2004, el espíritu del legislador nacional, al aumentar las penas para todos los delitos, surge como "una amable invitación para aceptar la responsabilidad penal lo más pronto posible y lograr la re- 
baja punitiva que ofrece el ordenamiento" (Molina, 2012, p. 357); de allí que resulta válido dudar de la libertad de decisión del procesado, con mayor preocupación si sucede en la primera oportunidad procesal, a saber, la audiencia de formulación de imputación, pues en ella se genera el mayor descuento punitivo, lo que puede mover la decisión del imputado pese al prominente desconocimiento de los medios probatorios y de las posibilidades de enfrentarlos en un juicio.

La situación descrita debería dar lugar a una preponderante estructura de protección de los derechos del procesado de cara a la aceptación de responsabilidad dentro de la audiencia de imputación; sin embargo, sucede lo inverso, puesto que el juez ante quien se realiza, es decir, el de control de garantías, no dicta la sentencia condenatoria derivada del allanamiento a cargos y es posible que no conozca siquiera los elementos materiales probatorios en que se funda la atribución jurídica que realiza la fiscalía, autoridad que tampoco está obligada a exhibirlos ante la defensa ni el procesado, por lo que la aceptación de cargos podría decirse que se realiza "a ciegas".

Distinto a lo que sucede en etapas posteriores del proceso, en las que está prevista la posibilidad de aceptar responsabilidad -audiencia preparatoria e inicio del juicio oral-, pues en estas la voluntad del procesado se expresa ante el juez de conocimiento, lo cual implica que ya se materializó el descubrimiento de los elementos materiales probatorios con los que cuenta el órgano de persecución penal ante la defensa técnica; tal oportunidad implica una mejor asesoría para el incriminado, quien podrá decidir si es de su interés aceptar la responsabilidad o ejercer a plenitud su defensa en la audiencia de juicio oral. Adviértase que la segunda oportunidad regulada para que el procesado acepte los cargos, es posterior al momento en el cual se ha surtido el descubrimiento de la evidencia de cargo, oportunidad en la cual se han analizado las posibilidades de éxito de la teoría del caso del ente acusador.

A lo anterior se suma el hecho de que, como es el juez de conocimiento el encargado de dictar sentencia de carácter condenatorio, fruto del allanamiento a cargos, para lo cual se debe exigir un alto grado de certeza sobre la existencia del hecho y la responsabilidad del procesado, resulta de mayor garantía que ante él -al amparo de los principios de inmediación y concentración- el procesado manifieste si desea aceptar responsabilidad penal a fin de que el funcionario realice la valoración correspondiente.

Así las cosas, acorde con lo expuesto puede afirmarse que los escenarios procesales en los que se otorga la posibilidad de aceptar responsabilidad, distintos a la formulación de imputación, salvaguardan en mejor medida el derecho constitucional al debido proceso; en tanto que, en esta última, como suele pasar, basta con que la fiscalía, en el mejor de los casos, realice una exposición clara y sucinta de los hechos jurídicamente relevantes, en un lenguaje comprensible, para que el procesado acepte responsabilidad. 
Suficiente es lo expuesto para concluir que si la aceptación de responsabilidad no fue voluntaria ni espontánea sino fruto de una coacción impropia derivada de una asesoría técnica limitada, del desconocimiento de los elementos de juicio que soportan la comunicación de cargos, y animada por el temor que implica enfrentarse a una sanción más drástica ante la incertidumbre de lo que pueda suceder en juicio, así como lo diría el maestro Roxin (2004), se trataría de una "autoincriminación involuntaria forzada estatalmente".

Como solución a la problemática, para análisis del lector se presentan dos posibles soluciones: la primera, devenida del análisis del presente artículo; la segunda, como una propuesta de lege ferenda, una eventual reforma al Código de Procedimiento Penal. Entonces, vale destacar que, entre las conclusiones del estudio realizado en este trabajo de investigación, se encuentra la que se puede enunciar así: es posible afirmar que una lectura correcta del artículo 293 del Código de Procedimiento Penal Colombiano (modificado L. 1453/2011, art. 69) conlleva intrínseca la posibilidad de retractación del procesado de la aceptación de cargos dentro del interregno específico que trascurre entre la formulación de imputación y el allanamiento a cargos, sin necesidad de sujetarla a justificación alguna, por las siguientes razones:

La hermenéutica del inciso primero del precepto legal en mención, en lo concerniente a la siguiente frase: "examinado por el juez de conocimiento el acuerdo para determinar que es voluntario, libre y espontáneo, procederá a aceptarlo sin que a partir de entonces sea posible la retractación de alguno de los intervinientes", resultó invariable, pues la modificación atrás señalada no lo afectó.

Por tanto, es válido pensar que -de antaño- el legislador previó que en el interregno entre la audiencia de imputación -dentro de la cual se puede generar la aceptación de responsabilidad- y la de verificación posterior ante el juez de conocimiento, hay un intervalo específico dentro del cual puede darse válidamente la retractación sin justificación o sustentación de ninguna índole, como de forma correcta lo analizó la Corte Suprema de Justicia, Sala de Casación Penal, en el radicado N. ${ }^{\circ} 37668$ del 30 de mayo de 2012. En esa oportunidad, se entendió la facultad de retractarse como un acto voluntario y libre, de arrepentimiento del procesado, derivado del ejercicio de sus derechos a la no autoincriminación, a la controversia de la prueba y al juicio oral.

La posibilidad emerge como una hipótesis distinta a la de retractación de que trata el parágrafo del artículo 293 de la Ley 906 de 2004 (introducido por el artículo 69 de la L. 1453/2011), en tanto que la exigencia de acreditar un vicio del consentimiento o vulneración de garantías fundamentales para lograr la retractación no obedece al sentido lógico del vocablo retractación, dado que se somete a condiciones de procedencia que en realidad son presupuestos de validez del acto los cuales, en todo caso, pueden ser objeto de discusión en cualquier etapa del proceso, incluso más técnicamente por vía de nulidad. Además, su análisis corresponde a la valoración del juez encargado de dictar la sentencia, con lo cual se separa de la 
voluntad del procesado, desconociendo sus derechos a la no autoincriminación, a la controversia de la prueba y al juicio.

La segunda propuesta que emerge de este trabajo, en el entendido de que la interpretación del precepto legal conforme lo decantó la jurisprudencia en las decisiones que ampliamente se refirieron, que es ahora contraria a la tesis esbozada, es la de una reforma legal para que la posibilidad de aceptar cargos se traslade de la audiencia de formulación de imputación a la audiencia de acusación, momento en el cual existe descubrimiento probatorio por parte de la fiscalía y el procesado realizaría la manifestación ante el juez encargado de dictar la sentencia, quien, luego de valorarla junto al material probatorio en que se sustenta la pretensión punitiva de la fiscalía, podría incluso fallar en la misma diligencia, lo cual no daría lugar a la retractación. Y en caso de acreditarse, eventualmente, vicios en el consentimiento o vulneración de garantías fundamentales, el ataque sobrevendría por la vía de la nulidad en los términos expuestos, al amparo de recursos ordinarios o mediante recursos extraordinarios como casación y revisión.

\section{Referencias}

Bazzani, D. (2006). Principio de oportunidad, negociaciones y aceptación de la responsabilidad en el Código de Procedimiento Penal. Bogotá: Escuela Rodrigo Lara Bonilla \& Universidad Nacional de Colombia.

Bernal, G. L. (2005). Las reformas procesales en Colombia. Revista Iusta, 22, 45-66.

Bernal, J. \& Montealegre, L. E. (2013). El proceso penal (6a. ed.), 2 t. Bogotá: Universidad Externado de Colombia.

Castaño, R. (2013). El sistema penal acusatorio en Colombia y el modelo de derecho penal premial. Análisis de las sentencias 36.502 de 2011 y 38.285 de 2012 de la Corte Suprema de Justicia y la sentencia C-645 de 2012 de la Corte Constitucional. Revista Nuevo Foro Penal, 9 (80), 165-185. Recuperado de http:/ / publicaciones. eafit.edu.co/index.php/nuevo-foro-penal / article/viewFile/2257 / 2187

Cortés, V. (1993). Derecho procesal Proceso Civil. Valencia: Tirant lo Blanch.

Damián, J. (2001). En la Nueva Ley de Enjuiciamiento Civil. Madrid: Tecnos.

Decreto 2700 (1991, noviembre 30). Por medio del cual se expiden y se reforman las normas de procedimiento penal. Presidencia de la República [Colombia]. Diario Oficial N. 40.190 de 30 de noviembre de 1991. Bogotá: Imprenta Nacional.

Del Moral, A. (2008). La conformidad en el proceso penal (reflexiones al hilo de su regulación en el ordenamiento español). Revista Auctoritas Prudentium, N. 1, 1-22. Recuperado de http: / / www.unis.edu.gt/ap/fetch/conformidadproceso-penal.pdf 
Del Río, C. (2008). El principio del consenso de las partes en el proceso penal y enjuiciamiento jurisdiccional: Aclaraciones conceptuales necesarias. Revista Chilena de Derecho, 35 (1), 157-182.

Díaz, A. M. (2014). El principio acusatorio en el modelo adversarial colombiano. Análisis en torno a su aplicación. Cuadernos de Derecho Penal, 11, 35-87. Recuperado de http:/ / revistas.usergioarboleda.edu.co/index.php/cuadernos_ de_derecho_penal/article/view/309/259

De Diego, L. A. (1999). Justicia Criminal Consensuada. Valencia: Tirant lo Blanch, 1999.

Espitia, F. (2006). Instituciones del Derecho Procesal Penal. Bogotá: Legis.

Fierro, H. (2012). La imputación y la acusación en el sistema penal acusatorio. Bogotá: Leyer.

Galain, P. (2005). La negociación en el proceso penal. Revista de Derecho de la Universidad Católica del Uruguay, Universidad Católica/ Konrad Adenauer Stiftung, 7, 159-201.

García de Paz, I. S. (2005). El coimputado que colabora con la justicia penal. Con atención a las reformas introducidas en la regulación española por las Leyes Orgánicas 7 / y 15/2003. Revista Electrónica de Ciencia Penal y Criminología, 1-33. Recuperado de http: / / criminet.ugr.es/ recpc/07/ recpc07-05.pdf.

Gimeno, V., Moreno, V. \& Cortés, V. (1999). Derecho Procesal Penal. Madrid: Colex.

Gómez, J. L. (2008). El sistema de enjuiciamiento criminal propio de un Estado de Derecho. México: Instituto Nacional de Ciencias Penales y Universitat Jaume I.

González, J. (2012) ¿Qué pasa con la pena hoy en día? Diálogos de Derecho y Política. Revista electrónica Facultad de Derecho y Ciencias Sociales, 8 (3), 1-13. Recuperado de https:/ / aprendeenlinea.udea.edu.co/revistas/index.php/derypol/article / view $/ 12318$

Guerrero, O. J. (2011). Fundamentos teórico constitucionales del nuevo proceso penal. (2a ed.). Bogotá: Nueva Jurídica.

Guerrero, O. J. (2017). Control de Garantías. Módulo de formación dirigida. Bogotá: Escuela Judicial "Rodrigo Lara Bonilla”.

Hinestrosa, F. (1986). Función, límites y cargas de la autonomía privada. Bogotá: Universidad Externado de Colombia.

Langbein, J. H. (1996). Sobre el mito de las constituciones escritas: la desaparición del juicio penal por jurados. En Bovino, B \& Courtis, C. (Trad.) Revista Nueva Doctrina Penal, 45-54. Recuperado de http:/ / www.pensamientopenal.com.ar / system/ files/2006/09/ doctrina30912.pdf 
Ley 57 (1887, abril 15). Sobre adopción de Códigos y unificación de la legislación Nacional. Congreso de la República [Colombia]. Diario Oficial N. ${ }^{\circ} 7019$ de abril 20 de 1887. Bogotá: Imprenta Nacional.

Ley $2^{a}$ (1984, diciembre 16). Por la cual se establece la competencia de la Policía. Congreso de la República [Colombia]. Diario Oficial N. ${ }^{\circ} 23095$ de 17 de enero de 1984. Bogotá: Imprenta Nacional.

Ley 600 (2000, julio 24). Por la cual se expide el Código de Procedimiento Penal. Congreso de la República [Colombia]. Diario Oficial N. ${ }^{\circ} 44.097$ de 24 de julio del 2000. Bogotá: Imprenta Nacional.

Ley 906 (2004, agosto 31). Por la cual se expide el Código de Procedimiento Penal. Congreso de la República [Colombia]. Diario Oficial N. ${ }^{\circ} 45658$ de 31 de agosto de 2004. Bogotá: Imprenta Nacional.

López, H. F. (2016). Código General del Proceso Parte General. Bogotá: Dupre Editores.

Maier, J, B. J. \& Bovino, A. (2001). El Procedimiento Abreviado. Buenos Aires, Editores del Puerto, 2001.

Maier, J, B, J. (2002). Derecho Procesal Penal. Buenos Aires: Editores del Puerto.

Manco, Y. (2012). La verdad y la justicia premial en el Proceso Penal Colombiano. Revista estudios de Derecho, 69 (153), 189-214. Recuperado de https:// aprendeenlinea.udea.edu.co/revistas/index.php/red/article/view/14146

Mendieta, C. (2014). Derecho del indiciado a conocer los hechos y elementos materiales probatorios por los cuales se le investiga antes de audiencia de formulación de acusación. Recuperado de http://www.javeriana.edu.co/ blogs / algomez / category / departamento-de-derecho-procesal /

Mesa, M. C. (2004) Derecho Procesal Civil Parte General (1a. ed). Bogotá, Biblioteca Jurídica.

Molina, R. (2012). La Conformidad en el proceso penal, análisis comparado de las legislaciones española y colombiana. Bogotá: Universidad de los Andes-Ibáñez.

Molina, R. (2015). Perspectivas y retos del proceso penal. En Duque Pedroza, A. F. (comp.), Justicia retributiva, justicia premial, justicia restaurativa y justicia transicional: ¿Diferentes verdades en el proceso penal? (pp. 138-143). Medellín: Pontificia Bolivariana.

Montañez, J. C. (2014). Justicia negociada y estado penitenciario. En Moreno Rivera, L. G. (coord.), Temas actuales de derecho penal y procesal penal (pp. 235-245). Bogotá: Nueva Jurídica.

Moreno, V. \& Cortés, V. (2008). Derecho Procesal Penal (3a. ed.). Valencia: Tirant Lo Blanch. 
Muñoz, O. (2006). Sistema penal acusatorio de Estados Unidos. Bogotá: Legis.

Ostos, J. M. (2015). Perspectivas y retos del proceso penal. En Duque Pedroza, A. F. (comp.), La verdad en el proceso penal (pp. 120-137). Medellín: Pontificia Bolivariana.

Pabón, C. \& Mora, A. (2014). Límites al ejercicio abusivo del derecho de retracto. Revista de Derecho y Economía, 4, 67-86. Disponible en revistas.uexternado.edu. co/index.php/contexto/article/download/3853/4108

Posada, R. (2015). Perspectivas y retos del proceso penal. En Duque Pedroza, A. F. (comp.), Hacia un nuevo modelo procesal acusatorio para los inimputables y quienes padezcan un grave estado de salud mental (pp. 57-81). Medellín: Pontificia Bolivariana

Ramírez, Y. (2010). Sistema Acusatorio Colombiano. Bogotá: Doctrina y Ley.

Reyes, L. (2010) Allanamiento a cargos y preacuerdos en el sistema penal acusatorio. Bogotá: Legis.

Roxin, C. (2004). Pasado, presente y futuro del derecho Procesal Penal. Bogotá: Instituto de estudios del Ministerio Público.

Sánchez, A, F. (2016). Acuerdos y allanamientos. Descubrimiento Probatorio anticipado. Bogotá: Universidad Externado de Colombia.

Sarabia, J. C. (2013). El allanamiento: manifestación voluntaria y unilateral de los cargos. Revistas CES DERECHO, 4 (1), 2-13. Recuperado de http:/ / revistas.ces. edu.co/index.php/derecho/article/view/2652

Saray, N. (2017). Procedimiento Penal Acusatorio. (2ª ed.) Bogotá: Leyer.

Saray, N. (2017bis) Preacuerdos y negociaciones entre la Fiscalía, el Imputado o Acusado. Bogotá: Leyer Editores.

Sentís, S. (1958). Teoría y práctica del proceso. Ensayos de Derecho Procesal. Buenos Aires: S.I.

Silvosa, J. M. (2008). El allanamiento en la Ley de Enjuiciamiento Civil. En Revista Internauta de Práctica Jurídica, 22, 29-65. Recuperado de https://www.uv.es/ ajv/art_jcos/art_jcos/num22 / allanamiento.pdf

Schünemann, B. (2002). ¿Crisis del procedimiento penal? (¿marcha triunfal del procedimiento penal americano en el mundo?). En: Temas actuales y permanentes del Derecho penal después del milenio (pp. 288-302). Madrid: Tecnos.

Schünemann, B. (2007). Sistema Penal Acusatorio. Aspectos problemáticos. Revista Iusta, 111-125. Recuperado de revistas.usta.edu.co/index.php/iusta/article/ download /3036/2903 
Sentencia (2013, febrero 21). Sentencia de segunda instancia [Radicado: 666823104001-2011-00071-01; Aprobado: Acta N. ${ }^{\circ}$ 77]. Magistrado Ponente: César Augusto López Londoño. Tribunal Superior de Distrito Judicial de Pereira, Sala Penal [Colombia].

Sentencia (2009, agosto 6). Recurso ordinario de súplica en reparación directa [Radicado N. ${ }^{\circ}$ 47001-23-31-000-1996-04835-00(17526)] Consejero Ponente: Mauricio Fajardo Gómez. Consejo de Estado, Sala de lo Contencioso Administrativo, Sección Tercera [Colombia].

Sentencia C-039 (1996, febrero 5). Acción de Tutela. Magistrado ponente: Antonio Barrera Carbonell. Corte Constitucional [Colombia].

Sentencia C-799 (2005, agosto 2). Acción de inconstitucionalidad. Magistrado ponente: Jaime Araujo Rentería. Corte Constitucional [Colombia].

Sentencia C-1195 (2005, noviembre 22). Acción de inconstitucionalidad. Magistrado ponente: Jaime Araujo Rentería. Corte Constitucional [Colombia].

Sentencia C-993 (2006, noviembre 29). Acción de inconstitucionalidad. Magistrado ponente: Jaime Araujo Rentería. Corte Constitucional [Colombia].

Sentencia C-303 (2013, mayo 22). Acción de inconstitucionalidad. Magistrado ponente: Luis Guillermo Guerrero Pérez. Corte Constitucional [Colombia].

Sentencia (2005, agosto 23). Recurso de casación. [Radicado N. 21954]. Magistrado ponente: Jorge Luis Quintero Milanés. Corte Suprema de Justicia, Sala de Casación Penal [Colombia].

Sentencia (2006, mayo 10). Recurso de casación. [Radicado N..$^{\circ}$ 25248]. Magistrado ponente: Mauro Solarte Portilla. Corte Suprema de Justicia, Sala de Casación Penal [Colombia].

Sentencia (2006, septiembre 7). Recurso de casación. [Radicado N. . 25765]. Magistrado ponente: Jorge Luis Quintero Milanés. Corte Suprema de Justicia, Sala de Casación Penal [Colombia].

Sentencia (2007, febrero 21). Recurso de casación. [Radicado N. ${ }^{\circ}$ 25920]. Magistrado ponente: Javier Zapata Ortiz. Corte Suprema de Justicia, Sala de Casación Penal [Colombia].

Sentencia (2007, febrero 21). Recurso de casación. [Radicado N. 2 26587]. Magistrado ponente: Marina Pulido Barón. Corte Suprema de Justicia, Sala de Casación Penal [Colombia].

Sentencia (2007, abril 11). Recurso de casación. [Radicado N. ${ }^{\circ}$ 26645]. Magistrado ponente: Mauro Solarte Portilla. Corte Suprema de Justicia, Sala de Casación Penal [Colombia]. 
Sentencia (2007, octubre 10). Recurso de casación. [Radicado N. ${ }^{\circ}$ 28161]. Magistrado ponente: Augusto J. Ibáñez Guzmán. Corte Suprema de Justicia, Sala de Casación Penal [Colombia].

Sentencia (2007, octubre 24). Recurso de casación. [Radicado N. ${ }^{\circ}$ 28433]. Magistrado ponente: Julio Enrique Socha Salamanca. Corte Suprema de Justicia, Sala de Casación Penal [Colombia].

Sentencia (2008, enero 30). Recurso de casación. [Radicado N..$^{\circ}$ 28772]. Magistrado ponente: Javier Zapata Ortiz. Corte Suprema de Justicia, Sala de Casación Penal [Colombia].

Sentencia (2008, febrero 13). Recurso de casación. [Radicado N. ${ }^{\circ}$ 28553]. Magistrado ponente: Jorge Luis Quintero Milanés. Corte Suprema de Justicia, Sala de Casación Penal [Colombia].

Sentencia (2008, marzo 31). Recurso de casación. [Radicado N. . 29180]. Magistrado ponente: Jorge Luis Quintero Milanés. Corte Suprema de Justicia, Sala de Casación Penal [Colombia].

Sentencia (2008, abril 8). Recurso de casación. [Radicado N. ${ }^{\circ}$ 25306]. Magistrado ponente: Augusto J. Ibáñez Guzmán. Corte Suprema de Justicia, Sala de Casación Penal [Colombia].

Sentencia (2008, octubre 22). Recurso de casación. [Radicado N. ${ }^{\circ}$ 29983]. Magistrado ponente: Alfredo Gómez Quintero. Corte Suprema de Justicia, Sala de Casación Penal [Colombia].

Sentencia (2009, septiembre 14). Recurso de casación. [Radicado N. ${ }^{\circ}$ 32032]. Magistrado ponente: Jorge Luis Quintero Milanés. Corte Suprema de Justicia, Sala de Casación Penal.

Sentencia (2011, marzo 23). Recurso de casación. [Radicado N. . 35771]. Magistrado ponente: Julio Enrique Socha Salamanca. Corte Suprema de Justicia, Sala de Casación Penal [Colombia].

Sentencia (2011, julio 11). Recurso de casación. [Radicado N. . 38285]. Magistrado ponente: Fernando Alberto Castro Caballero. Corte Suprema de Justicia, Sala de Casación Penal [Colombia].

Sentencia (2011, julio 27). Recurso de casación. [Radicado N. ${ }^{\circ}$ 35860]. Magistrado ponente: María Del Rosario González de Lemos. Corte Suprema de Justicia, Sala de Casación Penal [Colombia].

Sentencia (2011, diciembre 7). Auto interlocutorio. [Radicado N. ${ }^{\circ}$ 36367]. Magistrado ponente: José Luis Barceló Camacho. Corte Suprema de Justicia, Sala de Casación Penal [Colombia]. 
Sentencia (2012, marzo 21). Auto de segunda instancia. [Radicado N..$^{\circ}$ 38500]. Magistrado ponente: Sigifredo Espinosa Pérez. Corte Suprema de Justicia, Sala de Casación Penal [Colombia].

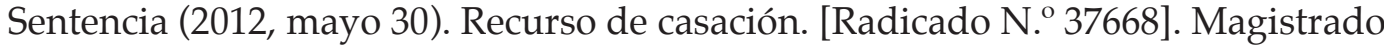
ponente: María Del Rosario González de Lemos. Corte Suprema de Justicia, Sala de Casación Penal [Colombia].

Sentencia (2013, febrero 13). Recurso de insistencia. [Radicado N. ${ }^{\circ}$ 39707]. Magistrado ponente: María Del Rosario González de Lemos. Corte Suprema de Justicia, Sala de Casación Penal [Colombia].

Sentencia (2013, febrero 13). Recurso de casación. [Radicado N. ${ }^{\circ}$ 40053]. Magistrado ponente: Gustavo Enrique Malo Fernández. Corte Suprema de Justicia, Sala de Casación Penal [Colombia].

Sentencia (2013, agosto 28). Recurso de casación. [Radicado N. . 40026]. Magistrado ponente: Gustavo Enrique Malo Fernández. Corte Suprema de Justicia, Sala de Casación Penal [Colombia].

Sentencia (2013, agosto 28). Recurso de casación. [Radicado N. ${ }^{\circ}$ 39566]. Magistrado ponente: Luis Guillermo Salazar Otero. Corte Suprema de Justicia, Sala de Casación Penal [Colombia].

Sentencia (2013, agosto 28). Recurso de casación. [Radicado N. ${ }^{\circ}$ 41419]. Magistrado ponente: María Del Rosario González de Lemos. Corte Suprema de Justicia, Sala de Casación Penal [Colombia].

Sentencia (2013, agosto 28). Recurso de casación. [Radicado N. ${ }^{\circ}$ 41295]. Magistrado ponente: Fernando Alberto Castro Caballero. Corte Suprema de Justicia, Sala de Casación Penal [Colombia].

Sentencia (2013, noviembre 20). Recurso de casación. [Radicado N. ${ }^{\circ}$ 39834]. Magistrado ponente: Fernando Alberto Castro Caballero. Corte Suprema de Justicia, Sala de Casación Penal [Colombia].

Sentencia AP830-2014 (2014, febrero 26). Recurso de casación. [Radicado 34699]. Magistrado ponente: José Leonidas Bustos Martínez. Corte Suprema de Justicia, Sala de Casación Penal [Colombia].

Sentencia STP223-2015 (2015, enero 22). Impugnación de Tutela. [Radicado 77358]. Magistrado ponente: Luis Guillermo Salazar Otero. Corte Suprema de Justicia, Sala de Casación Penal [Colombia].

Sentencia AP895-2015 (2015, febrero 25). Recurso de casación. [Radicado 4533]. Magistrado ponente: Luis Guillermo Salazar Otero. Corte Suprema de Justicia, Sala de Casación Penal [Colombia]. 
Sentencia AP2574-2015 (2015, mayo 20). Recurso de Apelación. [Radicado 45667]. Magistrado ponente: María Del Rosario González de Lemos. Corte Suprema de Justicia, Sala de Casación Penal [Colombia].

Urbano, J. J. (2008). Nueva estructura probatoria del proceso penal. Bogotá: Andrés Morales.

Vanegas, P. L. (2007). Las audiencias preliminares en el sistema penal acusatorio. Bogotá: Fiscalía General de la Nación.

Velásquez, F. (2010). La Justicia negociada: un ejemplo de peligro de la privatización del proceso penal con el nuevo sistema. En F. Velásquez (Comp.), Sistema Penal Acusatorio Nuevos Retos (pp. 13-42), Bogotá: Universidad Sergio Arboleda.

Verger, J. (1994). La defensa del imputado y el principio acusatorio. Barcelona: J.M Bosch.

Vigil, J. (2012, julio). La institución de la conformidad en el proceso penal español. Trabajo presentado en: II Jornadas de Direito Penal dos Açores. Recuperado de http: / / julgar.pt/ wp-content/uploads/2014/ 07 / Jacobo-Vigil-Levi-La-instituci\%C3\%B3n-dela-conformidade-en-el-proceso-penal-espa\%C3\%B1ol.pdf 